\title{
DIVERSITAS TIM MANAJEMEN PUNCAK, KEKOMPREHENSIFAN PENGAMBILAN KEPUTUSAN, INTEGRASI SOSIAL DAN KINERJA PERUSAHAAN: STUDI PADA BANK PERKREDITAN RAKYAT
}

\author{
Arief Prima Johan \\ Fakultas Ekonomi Universitas Andalas \\ e-mail: ariefprimajohan@gmail.com \\ Amin Wibowo \\ Fakultas Ekonomi dan Bisnis \\ Universitas Gadjah Mada Yogyakarta \\ e-mail: amin.wibowo@gadjahmada.edu
}

\begin{abstract}
Although research on diversity management team had been widely conducted, previous research defined diversity in many different ways and many studies focused their research on top management team of big companies and big industries. This study examined the influence of several type of diversity of top management team on decision-making comprehensiveness and social integration, and tests these last two variables on performance. Using data Rural Banks (banking industry), the results showed that several variables of diversity of top management team affect decision-making comprehensiveness and social integration. The study also confirmed that the company's performance is affected by decision-making comprehensiveness and social integration.
\end{abstract}

Keywords: Team Management, Diversity, Decision-Making Comprehensiveness, Social Integration, Performance.

\begin{abstract}
Abstrak
Meskipun penelitian mengenai diversitas tim manajemen sudah banyak dilakukan, tetapi penelitian yang lalu mendefinisikan diversitas dengan cara yang berbeda-beda dan banyak berfokus pada tim manajemen puncak perusahaan besar dan industri besar. Penelitian ini menguji pengaruh variablevariabel diversitas tim manajemen puncak perusahaan terhadap kekomprehensifan pengambilan keputusan dan integrasi sosial, serta menguji dua variable terakhir ini pada kinerja. Dengan menggunakan data Bank Perkreditan Rakyat (industri perbankan), hasil penelitian memperlihatkan bahwa beberapa variable diversitas manajemen puncak mempengaruhi kekomprehensifan pengambilan keputusan dan integrasi sosial.Penelitian juga mengkonfirmasi bahwa kinerja perusahaan dipengaruhi oleh kekomprehensifan pengambilan keputusan dan integrasi sosial.
\end{abstract}

Kata Kunci: Tim Manajemen Puncak, Diversitas, Kekomprehensifan, Pengambilan Keputusan, Integrasi Sosial, Kinerja Perusahaan.

\section{PENDAHULUAN}

Teori upper echelon yang dikemukakan Hambrick dan Mason (1984) menjadi pijakan awal yang menumbuhkan perhatian para peneliti pada topik kepemimpinan strategis, terutama tim manajemen perusahaan. Sudah banyak riset tentang hal ini di konteks negara maju dan industri yang besar (Neilsen, 2010). Namun, riset dengan konteks negara ber- kembang sekaligus industri yang lebih kecil namun kompetitif belum dilakukan. Di Negara berkembang seperti Indonesia, keberadaan Bank Perkreditan Rakyat (BPR) sangat penting untuk mendorong tumbuhnya perekonomian. Industri BPR adalah industri yang sangat penting dalam mendorong pertumbuhan dan pemerataan ekonomi. Industri ini telah menyalurkan kredit sebanyak Rp42.485 Milyar, 
meningkat lebih dari 20\% dari bulan Februari tahun sebelumnya sebanyak Rp34.860 Milyar dan menghidupi jutaan usaha bisnis nyata di Indonesia (Bank Indonesia, 2012). Adalah mengejutkan melihat signifikannya industri ini pada perekonomian namun amat langka studi dilakukan di bidang ini.

Sebagian besar riset pada bidang ini mempertanyakdan efek diversitas tim manajemen terhadap kinerja perusahaan (Finkeilstein et al., 2009), baik pengaruh langsung antara diversitas terhadap kinerja (Norburn and Birlet, 1988), melalui pengaruh yang dimediasi oleh variabel lain (Smith et al., 1994, Knight et al., 1999), maupun efek interaksi dengan variabel kontijensi lainnya (Simons et al., 1999). Sampai dengan saat ini, efek diversitas tim manajemen masih diperdebatkan (Lankau et al., 2007, Finkeilstein et al., 2009). Beberapa peneliti menemukan diversitas tim manajemen memberikan dampak positif kepada perusahaan karena kontribusi keragaman pengetahuan tim terhadap organisasi (Bantel and Jakson, 1989, Norburn and Birley, 1988, Bunderson and Sutclife, 2002, Bunderson, 2003). Sementara di sisi lainnya, diversitas dapat mengakibatkan konflik karena perilaku yang berbeda dari setiap anggota di dalam tim dapat memperburuk perilaku sosial (Smith et al., 1994, Knight et al., 1999, Simons et al., 1999, Lankau et al., 2009, Chou, 2011).

Beberapa alasan dapat dikemukakan mengenai hasil penelitian yang membingungkan ini. Pertama, para peneliti tidak memperhatikan defenisi yang berbeda dari berbagai variabel diversitas yang mereka gunakan (Harrison dan Klien, 2007). Mereka cenderung menggabungkan beberapa variabel diversitas yang berbeda ke dalam satu definisi konseptual yang sama (e.g. Smith et al.,1994, Knight et al.,1994, Simons et al., 1999). Kedua, mereka juga menggabungkan berbagai variabel, yang sebenarnya berbeda dalam hal konseptual, ke dalam satu mekanisme teori yang sama dalam membentuk argumentasi dugaan yang akan mereka uji (e.g. Bantel and Jackson, 1989, Hambrick et al., 1996, Smith et al.,1994, Knight et al.,1994, Simons et al., 1999).

Beberapa variabel dengan definisi konseptual yang berbeda seharusnya dioperasionalisasikan secara terpisah (Harrison dan Klien, 2007) karena masing-masing variabel tersebut mungkin memiliki efek yang berbeda terhadap satu variabel lain yang sama.Variabel yang berbeda secara konseptual seharusnya diargumentasikan secara terpisah dengan variabel lainnya yang memiliki perbedaan definisi konseptual (Kerlinger and Lee, 2000, Harrison and Klien, 2007).

Harrison dan Klien (2007) membagi diversitas ke dalam tiga bentuk berdasarkan definisi konseptual yaitu diversitas sebagai sebaran, variasi, dan disparitas. Ketiga diversitas tersebut juga diukur dengan metode pengukuran yang berbeda. Penelitian ini akan mengelaborasi variabel diversitas yang berbentuk sebaran dan variasi dengan mempertimbangkan kesamaan dan perbedaan antara masing-masing variabel tersebut. Diversitas sebagai disparitas tidak diteliti karena telah muncul sebagai nature di dalam tim manajemen perusahaan yang mana dipimpin oleh satu orang dengan beberapa orang lain sebagai anggota tim (Finkeilstein et al., 2009). Diversitas sebaran secara konseptual selanjutnya disebut sebagai diversitas kognitif karena mencerminkan variasi kognitif tim manajemen perusahaan, dan ditempatkan sebagai variable independen dalam penelitian ini. Sementara, secara konseptual diversitas variasi mencerminkan latar belakang fungsional dan latar belakang pendidikan, sehingga latar belakang itu akan dipakai sebagai variabel dalam penelitian ini dan diposisikan sebagai variabel independen. Penelitian ini juga menggusulkan variabel kekomprehensifan pengambilan keputusan dan integrasi sosial.

\section{KAJIAN PUSTAKA}

Diversitas sebagai sebaran didefinisikan sebagai perbedaan posisi masing-masing anggota kelompok dalam satu continuum terhadap satu atribut tertentu (Harrison dan Klien, 2007). Perbedaan dalam hal ini cenderung bersifat psikologikal seperti nilai, kepercayaan, orientasi dan lain sebagainya, yang mengakibatkan posisi masing-masing anggota dalam sebaran sulit untuk dirubah (Harrison and Klien, 2007, Miller et al., 1998, Chattopadhyay et al., 1999). Diversitas kognitif sebagai diversitas yang berbentuk sebaran memiliki definisi sejauh mana perbedaan keyakinan antar anggota tim manajemen perusahaan dalam hal preferensi tujuan organisasi dan hubungan sebab-akibat yang 
mempengaruhi preferensi tersebut (Miller et al., 1998). Definisi ini memperlihatkan posisi masing-masing anggota dalam satu continuum pada atribut keyakinan terhadap preferensi tujuan perusahaan (Miller et al., 1998, Chattopadhyay et al., 1999).

Diversitas sebagai variasi diartikan sebagai perbedaan atribut masing-masing anggota di dalam tim yang mana perbedaan tersebut berbentuk kualitatif atau kategorikal (Harrison and Klien, 2007). Definisi ini menginplikasikan bahwa masing-masing anggota yang berbeda secara variasi bersifat mutualy exlcusive dengan anggota lainnya dalam satu atribut tertentu. Perbedaan anggota dalam latar belakang fungsional dan pendidikan merupakan perbedaan yang berbentuk kategorikal (Harrison dan Klien, 2007), oleh karena itu digunakan dalam penelitian ini. Perbedaan tersebut merupakan cerminan dari perbedaan pengetahuan, keahlian dan kemampuan masingmasing anggota (Bunderson, 2003, Bunderson and Sutclife, 2002, Bunderson and McGrath, 1995 dalam Harrison and Klien, 2007).

Kekomprehensifan merupakan konsep yang berkaitan erat dengan proses pengambilan keputusan (Frederickson, 1984). Konsep ini mencirikan tingkat rasionalitas para pengambil keputusan dalam melakukan proses pengambilan keputusan (Papadakis et al., 1998, Frederickson and Mitchell, 1984). Kekomprehensifan dapat didefinisikan sebagai sejauh mana tim manajemen perusahaan mempertimbangkan berbagai aspek secara luas dan menyeluruh dalam proses pengambilan keputusan ketika berhadapan dengan kesempatan atau ancaman yang mana keputusan harus segera dieksekusi (Miller et al., 1998). Proses pengambilan keputusan yang komprehensif dicirikan oleh kompleksitas metodologi analisis, tingkat investigasi, ketelitian, pencarian berbagai alternatif keputusan dan pengujian alternatif tersebut (Papadakis et al., 1998, Miller et al., 1998).

Integrasi sosial merupakan salah satu elemen proses dalam kajian tim manajemen perusahaan. Proses ini mencerminkan bagaimana hubungan interaksi dan keterkaitan antara anggota tim di dalam organisasi (Finkeilstein et al., 2009). Konsep ini mencerminkan perilaku informal antar anggota-anggota di dalam tim, termasuk keinklusifan atau keeklusifan anggota di dalam tim (O'Reilly et al., 1989, Smith et al.,
1994, Finkeilstein et al., 2009, Chou, 2011). Integrasi sosial didefinisikan sebagai ketertarikan anggota kelompok terhadap kelompoknya, kepuasan terhadap sesama anggota di dalam kelompok, dan interaksi sosial antar anggota di dalam kelompok (O'Reilly et al., 1989). Ketertarikan ini lebih dibentuk oleh faktor afektif dari pada aturan dan birokrasi. Hal ini mengindikasikan bahwa kepuasan anggota tim terhadap anggota lainnya dan motivasi mereka untuk terus membangun hubungan merupakan bagian penting dari integrasi sosial (O'Reilly et al., 1989).

\section{PENGEMBANGAN HIPOTESIS}

Proses pengambilan keputusan terutama yang bersifat komprehensif terdiri dari beberapa tahapan yang sistematis. Tahapan tersebut dimulai dari membahas dan mengidentifikasi masalah organisasi, mengidentifikasi alternatif solusi, mengevaluasi masing-masing alternatif, pada akhirnya mengambil keputusan (Finkeilstein et al., 2009: 152). Diversitas kognitif yang pada dasarnya bersifat tahan lama dan sulit dirubah (Miller et al., 1998, Chattopadhyay et al., 1999), menyulitkan tim untuk beranjak dari satu tahap ke tahapan berikutnya dalam proses pengambilan keputusan karena terdapat pertentangan yang kuat diantara anggota mengenai tujuan dan hubungan sebab-akibat yang diyakini mempengaruhi kinerja organisasi. Teori konsistensi bisa membantu menjelaskan mengapa pengambil keputusan menjaga konsistensi antara sikap dan keputusan, dan ini memungkinkan pengambil keputusan bersikap tidak sama dengan anggota tim yang lain (Kiesler and Sproul, 1982). Perbedaan tersebut juga mengakibatkan perbedaan pandangan terhadap alternatif pilihan yang tepat dan konsekuensi dari alternatif tersebut terhadap masa depan organisasi (Hambrick dan Mason, 1984). Efek perbedaan kognitif juga mengakibatkan proses komunikasi yang buruk dan ambigu antar anggota (Lankau et al., 2007). Semakin tinggi diversitas kognitif di dalam tim akan semakin sulit bagi mereka untuk komprehensif dalam proses pengambilan keputusan. Oleh karena itu dirumuskan hipotesis sebagai berikut:

H1: Diversitas kognitif tim manajemen perusahaan berpengaruh negatif terhadap kekomprehensifan dalam pengambilan keputusan. 
Anggota tim yang berbeda dalam hal sebaran cenderung oposisi terhadap anggota lainnya yang berbeda dalam hal sebaran (Harrison and Klien, 2007). Keoposisian terhadap anggota lain yang diperlihatkan secara eksplisit melalui sikap dan perilaku dapat memperburuk konflik personal yang biasanya telah terjadi sebelumnya (Miller et al., 1998, Lankau et al., 2007, Chou, 2011). Karena tim manajemen perusahaan harus mengambil dan mengeksekusi satu keputusan dan mengeliminasi alternatif lain, akan muncul ketidakpuasan dari anggota terhadap tim dan anggota lainnya di dalam tim jika keputusan tersebut berseberangan dengan nilai dan keyakinan mereka (Lankau et al., 2007, Cunningham, 2007). Konsistensi teori kembali menjelaskan mengapa seorang pengambil keputusan mendiskonto data atau informasi yang berbeda dengan yang diyakininya dan menantang nilainilai yang diyakinininya (Kiesler and Sproul, 1982). Data atau informasi itu dapat bersumber dari anggota lain dalam tim. Ketidakpuasan tersebut akan meningkatkan konflik interpersonal (Barsade et al., 2000) dan menurunkan integrasi sosial antar anggota (Smith et al., 1994, Chou, 2011). Dengan demikian, semakin tinggi diversitas kognitif tim manajemen perusahaan akan memperburuk integrasi sosial di dalam tim tersebut.

H2: Diversitas kognitif tim manajemen perusahaan berpengaruh negatif terhadap integrasi sosial.

Latar belakang fungsional dan latar belakang pendidikan berkaitan dengan diversitas pengetahuan, keahlian dan kemampuan di dalam tim (Harrison and Klien, 2007, Weiserma and Bantel, 1992). Dasar pengetahuan, keahlian dan kemampuan seseorang akan mengarahkan mereka kepada sumber informasi utama yang berbeda yang mana dapat memperkaya informasi dalam proses pengambilan keputusan (Bantel and Jackson, 1989, Dahlin et al., 2005). Dengan sumber informasi yang lebih banyak dari berbagai fungsi yang ada, pengambil keputusan mampu memunculkan berbagai alternatif keputusan dari berbagai perspektif yang menjadikan proses pengambilan keputusan lebih komprehensif (Frederickson, 1984, Papadakis et al., 1998, Goll et al., 2001, Miller, 2008). Beberapa peneliti telah menemukan hubungan positif antara diversitas latar belakang fungsional dan latar belakang pendidikan terhadap penggunaan dan kedalaman informasi (Dahlin et al., 2005), inovasi (Bantel and Jackson, 1989; Oslon and Twigg, 2006), dan keluasan aksi perusahaan (Hambrick et al., 1996). Dengan mempertimbangkan argumentasi tersebut di atas, maka hipotesis yang dibangun adalah:

H3a: Diversitas latar belakang fungsional berpengaruh positif terhadap kekomprehensifan pengambilan keputusan.

H3b: Diversitas latar belakang pendidikan berpengaruh positif terhadap kekomprehensifan pengabilan keputusan.

Pengetahuan, keahlian dan kemampuan yang berbeda membutuhkan proses integrasi agar dapat dimanfaatkan oleh perusahaan (Hedlund, 1994, Grant, 1996). Untuk mengintegrasikan pengetahuan, keahlian dan kemampuan yang berbeda-beda organisasi membutuhkan serangkaian upaya koordinasi berupa prosedur dan birokrasi tertentu (Smith et al., 1994, Hedlund, 1994, Grant, 1996). Serangkaian prosedur formal akan mengurangi interaksi antar anggota tim (Smith et al., 1994; Grant, 1996, Bunderson and Sutclife, 2002).

Integrasi sosial juga berkaitan dengan ketertarikan dan keatraktifan antar anggota di dalam tim (O'Reilly et al., 1989). Anggota tim dengan atribut yang berbeda akan lebih sulit tertarik dan atraktif terhadap anggota lainnya (Kearney et al., 2009, Reagans, 2005, Chou, 2011). Knight et al. (1999) dan Lankau et al. (2007) menemukan hubungan positif antara diversitas latar belakang fungsional dan latar belakang pendidikan terhadap konflik. Dengan adanya konflik, baik konflik pekerjaan maupun konflik personal, akan mengurangi kepuasan antar sesama anggota (Lankau et al., 2007). Ketidakpuasan antar anggota akan memperburuk integrasi sosial di dalam tim (O'Reilly et al., 1989, Smith et al., 1994). Konsep berpikir ala sangkar (silo) yang berpedoman bahwa hanya fungsi anggota yang bersangkutan yang penting, dan yang berkontribusi besar pada organisasi mempersulit integrasi sosial dalam manajemen perusahaan.Beberapa peneliti telah menemukan hubungan negatif antar diversitas latar belakang fungsional dan latar belakang pendidikan tim manajemen perusahaan terhadap integrasi sosial (e.g. O'Reilly et al., 1989, Smith et al., 1994, Bunderson, 2002, 
Reagans, 2005, Simsek et al., 2005, Kearney et al., 2009, Chou, 2011). Dengan demikian, dapat dihipotesiskan bahwa:

H4a: Diversitas latar belakang fungsional berpengaruh negatif terhadap integrasi sosial.

H4b: Diversitas latar belakang pendidikan berpengaruh negatif terhadap integrasi sosial.

Proses pengambilan keputusan yang komprehensif dicirikan oleh kepemilikian informasi yang luas (Frederickson, 1984). Dengan kepemilikan informasi tersebut, keputusan diambil tidak hanya berdasarkan batasan rasionalitas yang dimiliki sehingga mampu mengurangi kognitif bias, tetapi juga meningkatkan akurasi persepsi tim manajemen perusahaan dalam proses pengambilan keputusan (Miller, 2008).

Proses pengambilan keputusan yang komprehensif melibatkan pengujian terhadap berbagai alternatif keputusan dengan kondisi internal perusahaan (Miller et al., 1998; Frederickson, 1984, Frederickson and Mitchell, 1984, Iaquinto and Frederickson, 1997). Melalui proses pengujian dan integrasi keputusan terhadap kondisi internal, keputusan yang diambil akan lebih rasional dan memiliki kesesuaian antara permasalahaan yang dihadapi dengan kondisi internal perusahaan. Kesesuaian anatara keputusan yang diambil dengan permasalahan dan kondisi internal dapat meningkatkan kinerja perusahaan (Venkatraman, 1989, Chorn, 1991). Dengan demikian, diversitas tim manajemen perusahaan dapat menentukan tingkat kekomprehensifan proses pengambilan keputusan yang mana pada akhirnya akan menentukan kinerja perusahaan.

H5: Kekomprehensifan proses pengambilan keputusan berpengaruh positif terhadap kinerja perusahaan

Integrasi sosial sebagai bentuk kohesi dapat meningkatkan efisiensi di dalam tim karena tim yang anggota-anggotanya terintegrasi tidak membutuhkan banyak waktu dan energi untuk melakukan konsolidasi dan koordinasi perilaku anggotanya dalam melakukan pekerjaan (O'Reilly et al., 1989, Smith et al., 2009). Dengan efeisiensi ini, tim memiliki sumberdaya yang lebih untuk membahas isuisu yang lebih stratgis (Smith et al., 1994) dan menjadikan perusahaan lebih responsif (Hambrick et al., 1996).

Dengan integrasi sosial yang tinggi, maka anggota tim akan saling merasa terikat satu sama lain secara informal dan emosional yang akan meningkatkan pula keterlibatan mereka di dalam tim (Sparrowe et al., 2001). Keterlibatan yang tinggi dari masing-masing anggota akan meningkatkan kinerja perusahaan karena masing-masing anggota akan melakukan usaha terbaik untuk mencapai tujuan perusahaan sebagai konsekuensi dari keterikatan emosional mereka ke dalam tim. Tim yang memiliki integrasi sosial yang tinggi akan berkinerja lebih baik (O'Reilly, 1989, Smith et al., 1994, Barrick et al., 2007,Johnson et al., 2007, Whiteoak, 2007).

H6: Integrasi sosial berpengaruh positif terhadap kinerja perusahaan

\section{METODE PENELITIAN Data dan sampel}

Data penelitian berupa data primer dan data skunder. Data primer dikumpulkan melalui kuesioner yang diisi oleh masing-masing tim manajemen perusahaan. Sedangkan data sekunder diambil dari laporan keuangan BPR yang dipublikasikan oleh Bank Indonesia.

Sampel pada penelitian ini adalah Bank Perkreditan Rakyat (BPR) yang beroperasi di wilayah Sumatera Barat. Kuesioner dikirimkan kepada 80 BPR yang ditentukan secara random. Setelah pengiriman kuesioner, masing-masing perusahaan dihubungi melalui telepon untuk mengkonfirmasi penjemputan kuesioner. Kuesioner yang telah dikirimkan dijemput ke masing-masing kantor BPR setelah dua minggu setelah pengiriman.Sebanyak 66 perusahaan mengisi kuesioner tersebut. Setelah dilakukan tabulasi, hanya 53 perusahaan yang bisa dianalisis lebih lanjut karena terdapat kesalahan pengisian oleh tiga perusahaan dan terdapat nilai ekstrim pada perusahaan lainnya. Jumlah tim manajemen minimum adalah tiga dan maksimum adalah lima.

\section{Pengukuran Variabel}

Kognitif tim manajemen perusahaan diukur menggunakan empat item pertanyaan dengan skala satu sampai tujuh yang dikembangkan oleh Miller et al. (1998). Untuk mengukur diversitas kognitif digunakan standar deviasi 
(Harrison and Klien, 2009). Setelah dilakukan pengumpulan data, tingkat internal konsistensi antar indikator pada variabel ini dilihat dari nilai cronbach's alpha adalah sebesar 0,79. Latar belakang fungsional diidentifikasi dengan cara meminta responden untuk memilih dan menyebutkan salah satu latar belakang fungsional yang paling mencerminkan latar belakang fungsional mereka (Hambrick et at., 1996, Bunderson, 2003). Sedangkan latar belakang pendidikan diidentifikasi melalui jurusan pendidikan terakhir masing-masing anggota tim manajemen perusahaan (Hambrick et al., 1996). Latar belakang fungsional dan latar belakang perndidikan diukur menggunakan indeks Blau. Indeks Blau digunakan karena indeks ini dapat mengukur keragaman antar anggota yang memiliki perbedaan secara kategorikal (Harrison dan Klien, 2007). Untuk mendapatkan skor indeks Blau adalah $d=1-$ $\sum p_{k}^{2}$, dimana $d$ adalah nilai indeks $p_{k}$ adalah proporsi anggota dalam kategori $k$.

Kekomprehensifan diukur menggunakan lima item pertanyaan dengan skala satu sampai tujuh yang dikembangkan oleh Miller et al. (1998). Nilai cronbach's alpha yang menunjukkan tingkat internal kosistensi variabel ini adalah sebesar 0,81 . Integrasi sosial diukur menggunakan sembilan item pertanyaan yang dikembangkan oleh Smith et al. (1994). Tingkat internal konsistensi antar indikator adalah sebesar 0,71. Kinerja perusahaan dilihat melalui nilai return on equity (ROE) masingmasing BPR pada tahun pengamatan.

\section{Variabel Kontrol}

Nilai total aset menjadi variabel kontrol pada penelitian ini karena ukuran perusahaan dapat menentukan kinerja perusahaan. Ukuran perusahaan yang dicerminkan oleh nilai aset menunjukkan kepemilikan sumber daya yang dimiliki oleh perusahaan (Bantel and Jackson, 1989, Smith et al., 1994, Weiserma and Bantel, 1992). Ketidakpastian lingkungan juga dijadikan kontrol karena adanya perdebatan mengenai efek kekomprehensifan pada berbagai kondisi lingkungan (Miller et al., 1998, Miller, 2008). Ketidakpastian lingkungan diukur menggunakan empat item pertanyaan dengan skala satu sampai tujuh yang dikembangkan oleh Miller et al. (1998). Internal konsistensi antar indikator adalah sebesar 0,62. Rata-rata tingkat pendidikan tim manajemen puncak juga dijadikan sebagai variabel kontrol. Tim manajemen puncak yang berpendidikan tinggi menunjukkan kinerja yang lebih baik dan diasosiasikan memiliki kemampuan inovasi yang lebih tinggi (Bantel and Jackson, 1989, Srivastava and Lee, 2008).

\section{HASIL ANALISIS}

Analisis dan pengujian hipotesis dilakuakan dengan teknik regresi hirarki. Pengujian mediasi mengikuti prosedur pengujian Baron and Kenny (1986). Sebelum melakukan analisis regresi, asumsi klasik (normalitas, multikolinieritas, dan heteroskedastisitas) data diuji terlebih dahulu. Hasil uji asumsi klasik menunjkkan bahwa da ta penelitian memenuhi semua asumsi untuk dilakukan analisis regresi dan telah memenuhi best linier unbiased estimation (BLUE).

Tabel 1 memperlihatkan deskripsi data berupa rerata, standar deviasi dan korelasi antar variabel.

Tabel 1: Rerata, Standar Deviasi, dan Korelasi Dari Semua Variabel

\begin{tabular}{|c|c|c|c|c|c|c|c|c|c|c|c|}
\hline & Mean & S.D. & $\mathrm{TP}$ & $\mathrm{TA}$ & $\mathrm{KL}$ & DP & DF & DK & KP & IS & ROE \\
\hline $\mathrm{TP}$ & 1,8267 & 0,192 & 1 & & & & & & & & \\
\hline TA & 12688344 & 8123141,1 & $-0,01$ & 1 & & & & & & & \\
\hline $\mathrm{KL}$ & 3,9153 & 0,92 & $-0,04$ & 0,077 & 1 & & & & & & \\
\hline DP & 0,7871 & 0,29 & $-0,06$ & 0,008 & $-0,03$ & 1 & & & & & \\
\hline DF & 0,6748 & 0,24 & $-0,05$ & $-0,01$ & $-0,04$ & 0,06 & 1 & & & & \\
\hline DK & 0,3195 & 0,24 & 0,084 & $-0,13$ & $-0,1$ & 0,2 & $0,25^{*}$ & 1 & & & \\
\hline KP & 5,5513 & 0,46 & $-0,2$ & $0,3 *$ & 0,12 & 0,00 & $-0,1$ & $-0,34 * *$ & 1 & & \\
\hline IS & 5,9756 & 0,45 & $-0,24 *$ & $0,26 *$ & 0,13 & 0,12 & 0,02 & $-0,28 *$ & $0,5 * *$ & 1 & \\
\hline $\mathrm{ROE}$ & 18,5941 & 10,6 & $-0,05$ & 0,179 & 0,08 & $-0,23 *$ & $-0,02$ & $-0,2$ & $0,47 * *$ & $0,39 *$ & 1 \\
\hline \multicolumn{10}{|c|}{$* p<0,05, * * p<0,01$} & \multicolumn{2}{|c|}{ Catatan: } \\
\hline \multicolumn{3}{|c|}{$\begin{array}{l}\text { TP: Tingkat Pendidikan } \\
\text { DP: Diversitas Pendidikan } \\
\text { KP: Kekomprehensifan }\end{array}$} & \multicolumn{3}{|c|}{$\begin{array}{l}\text { TA: Total Aset } \\
\text { DF: Diversitas Fungsional } \\
\text { IS: Integrasi Sosial }\end{array}$} & & \multicolumn{4}{|c|}{$\begin{array}{l}\text { KL: Ketidakpastian Lingkungan } \\
\text { DK: Diversitas Kognitif } \\
\text { ROE: Return on Equity }\end{array}$} & \\
\hline
\end{tabular}


Table 2: Hasil Analisis Regresi Hirarki Pengujian Hipotesis

\begin{tabular}{cccccc}
\hline Variabel Independen & Model 1 & \multicolumn{2}{c}{ Model 2 } & \multicolumn{2}{c}{ Model 3 } \\
\hline & ROE & Komp & Integrasi & \multicolumn{2}{c}{ ROE } \\
\cline { 2 - 6 } TP & -0.56 & $-0,179$ & $-0,201$ & 0,025 & 0,024 \\
TA & 0,188 & $\mathbf{0 , 2 5 6} *$ & 0,200 & 0,071 & 0,109 \\
KL & 0,043 & 0,068 & 0,092 & 0,012 & 0,007 \\
DP & $-0,232$ & 0,027 & 0,144 & $-\mathbf{0 , 2 4 5 *}$ & $-0,289$ \\
DF & 0,026 & $-0,038$ & 0,084 & 0,043 & $-0,008$ \\
DK & $-0,128$ & $\mathbf{- 0 , 2 7 9 *}$ & $\mathbf{- 0 , 2 8 6 * *}$ & 0,000 & $-0,014$ \\
KP & & & & $\mathbf{0 , 4 5 7 * *}$ & \\
IS & & & & & $\mathbf{0 , 3 9 7 * *}$ \\
F & 1,039 & $\mathbf{2 , 1 9 1 *}$ & $\mathbf{2 , 1 2 8 *}$ & $\mathbf{2 , 5 2 3 * *}$ & $\mathbf{2 , 0 6 8}$ \\
R & 0,119 & 0,222 & 0,217 & 0,282 & 0,243 \\
$\Delta \mathrm{R}^{2}$ & & & & 0,185 & 0,147 \\
\hline
\end{tabular}

$* p<0,05, * * p<0,01$

Tabel 2 berisi hasil analisis multiple regresi yang digunakan untuk pengujian hipotesis. Model 1 dalam persamaan regresi yang hasilnya ditampilkan pada Tabel 2 adalah menjelaskan hasil pengujian hubungan langsung antara variabel independen terhadap variabel dependen. Model 2 pada Tabel 2 merupakan penjelasan dari hasil pengujian antara variabel independen terhadap variabel mediasi. Pada model ini, hipotesis yang diuji adalah hipotesis pertama sampai keempat. Sedangkan model 3 pada Tabel 2 adalah hasil pengujian antara variabel independen dan mediasi secara bersamaan terhadap variabel denpenden. Model ini menguji hipotesis lima dan enam.

Dengan demikian, dapat disimpulkan sebagai berikut: Hipotesis 1 yang mengatakan diversitas kognitif berpengaruh negatif terhadap kekomprehensifan didukung oleh data penelitian $(\beta=-0,279, p<0,10)$. Hipotesis 2 , diversitas kognitif berpengaruh negatif terhadap integrasi sosial juga didukung oleh data $(\beta=-0,286, p<0,05)$. Hubungan antara diversitas latar belakang fungsional terhadap kekomprehensifan proses pengambilan keputusan pada hipotesis 3a tidak didukung oleh data penelitian $(\beta=0,026)$. Hipotesis $3 b$ yang memprediksi hubungan diversitas latar belakang pendidikan terhadap kekomprehensifan proses pengambilan keputusan juga tidak didukung $(\beta=-0,232)$. Hipotesis $4 a$ dan $4 \mathrm{~b}$ yang mana masing-masing mengatakan bahwa diversitas latar belakang fungsional dan latar belakang pendidikan berpengaruh negatif terhadap integrasi sosial tidak didukung oleh data penelitian $(\beta=-0,038$ dan $\beta=0,027)$. Hipotesis 5 yang menyatakan kekompre- hensifan proses pengambilan keputusan berpengaruh positif terhadap kinerja perusahaan didukung oleh data $(\beta=0,457)$. Demikian juga dengan hipotesis 6 yang memprediksi integrasi sosial berpengaruh positif terhadap kinerja perusahaan juga didukung oleh data penelitian $(\beta=0,397)$. Mengacu kepada Baron dan Kenny (1986) terdapat hubungan antara diversitas kognitif terhadap kinerja perusahaan yang dimediasi secara penuh oleh kekomprehensifan proses pengambilan keputusan. Terdapat hubungan antara diversitas kognitif dan kinerja perusahaan yang dimediasi secara penuh oleh integrasi sosial.

\section{PEMBAHASAN}

Didukungnya hipotesis 1 oleh data penelitian yang mengatakan bahwa diversitas kognitif berpengaruh negatif terhadap kekomprehensifan mengindikasikan bahwa tim manajemen yang memiliki keyakinan yang berbeda, baik yang bersifat keyakinan normatif maupun keyakinan terhadap hubungan sebab akibat menyulitkan mereka untuk melakukan proses pengambilan keputusan yang komprehensif. Hasil penelitian ini mendukung teori bahwa tim yang anggotanya semakin berbeda dalam hal keyakinan, sulit beranjak dari satu tahap ke tahapan berikutnya dalam proses pengambilan keputusan karena terdapat pertentangan diantara mereka mengenai tujuan dan hubungan sebab akibat yang diyakini memperngaruhi kinerja perusahaan (Miller et al., 1998, Lankau et al., 2007). Teori konsistensi terbukti disini bahwa ketika satu manajer mempertahankan keyakinannya dan manajer lain juga berperilaku sama, maka akan terdapat pertentangan 
diantara mereka yang berakibat pada tidak tercapainya kekomprehensifan pengambilan keputusan.

Hipotesis 2 yang mengatakan bahwa diversitas kognitif berpengaruh negatif terhadap integrasi sosial didukung oleh data penelitian. Hasil tersebut mendukung teori similarity attractionyang digunakan pada hipotesis yang mengatakan bahwa anggota tim yang memiliki kesamaan karakteristik akan lebih tertarik untuk berinteraksi dengan anggota tim lain yang memiliki kesamaan dengan dirinya (Lankau et al., 2007, Cunningham, 2007, Simsek et al., 2005). Kecenderungan untuk berinteraksi dengan anggota yang memiliki kesamaan kharakterisktik tidaklah berbeda dengan konsep groupthink yang pada akhirnya membawa dampak negatif pada integrasi sosial.

Hipotesis $3 \mathrm{a}$ dan $3 \mathrm{~b}$ yang merumuskan diversitas latar belakang pendidikan dan diversitas latar belakang fungsional berpengaruh positif terhadap kekomprehensifan tidak didukung oleh data penelitian. Sebagaimana dijelaskan pada landasan teori bahwa kedua variabel tersebut merupakan cerminan dari keragaman pengetahuan, kemampuan, dan keahlian anggota-anggota tim manajemen (Bunderson and Sutclife, 2002, Bunderson, 2003, Harrison and Klien, 2007). Penjelasan atas hubungan yang tidak signifikan mungkin karena latar belakang pendidikan dan latar belakang fungsional tidak cukup mampu menjelaskan keragaman pengetahuan, kemampuan dan keahlian anggota tim manajemen perusahaan dalam konteks BPR. Finkelstein and Hambrick (1990) mengatakan bahwa efek keragaman diversitas kepemimpinan strategis akan lebih terlihat pada perusahaan yang berada pada industri dengan tingkat regulasi yang rendah dan komplek. Pada industri dengan regulasi yang rendah, tim manajemen puncak memiliki fleksibilitas dalam merancang dan mengambil keputusan perusahaan, sedangkan pada industri yang kompleks, perusahaan membutuhkan tim manajemen yang lebih heterogen dalam hal pengetahuan (Finkeilstein et al., 2009). Regulasi yang ketat pada industri perbankan, khususnya BPR, yang mengatur operasionalisasi perusahaan secara lebih detil mengakibatkan pola kerja menjadi sangat rinci dan terstruktur sehingga dalam proses pengambilan keputusan, tim manajemen puncak lebih banyak mengacu kepada regulasi industri mereka. Kondisi ini mengakibatkan efek pengetahuan yang dimiliki oleh masingmasing anggota tidak terlalu berperan besar dalam proses pengambilan keputusan yang komprehensif.

Hipotesis 4a dan 4b juga tidak didukung oleh data penelitian.Penjelasan yang mungkin atas hasil ini adalah kondisi kontekstual yang dihadapi oleh BPR yang tidak berada pada industri dengan kompleksitas yang tinggi. Walaupun berada pada industri yang teregulasi, perilaku sosial antar anggota tim manajemen puncak BPR tidak membutuhkan standarisasi yang tinggi karena sistem kerja yang tidak rumit dan ukuran perusahaan yang relatif kecil. Perusahaan dengan ukuran yang kecil dan kompleksitas yang rendah tidak terlalu membutuhkan aturan-aturan formal untuk menstandarisasi perilaku orang-orang yang berada pada perusahaan tersebut (Mintzberg et al., 2003: 217). Prosedur formal yang rendah memungkinkan terjadinya hubungan sosial dan integrasi sosial yang lebih baik melalui komunikasi informal dan kemungkinan interaksi sosial yang lebih sering (Smith et al., 1994). Kondisi kontekstual tersebut mungkin mereduksi pengaruh keragaman pengetahuan, keahlian, dan kemampuan antar anggota dalam berperilaku dan berintegrasi di dalam tim.

Penjelasan lain tidak didukungnya hipotsis 3a dan 4a adalah adanya kemung kinan variabel diversitas latar belakang fungsional kurang mencerminkan keragaman pengetahuan antar anggota yang disebabkan oleh efek tenure masing-masing anggota pada bidang fungsional mereka saat ini dan pengalaman mereka pada area fungsional lainnya (Bunderson, 2003). Bunderson (2003) mengemukakan konsep latar belakang fungsional intrapersonal yang mana mengindikasikan keterlibatan anggota dalam beberapa area fungsional dengan mempertimbangkan lama mereka bekerja pada masing-masing area fungsional tersebut. Nilai latar belakang fungsional intrapersonal yang tinggi mengindikasikan anggota-anggota tim manajemen memiliki pengalaman pada banyak area fungsional yang berbeda-beda. Konsep ini memiliki pengaruh terhadap keberagaman pengetahuan yang dimiliki tim manajemen (Bunderson, 2003). 
Kekomprehensifan proses pengambilan keputusan berpengaruh positif terhadap kinerja perusahaan. Hasil pengelitian ini mendukung studi sebelumnya yang dilakukan oleh Frederickson (1984), Miller et al. (1998) dan Miller (2008). Dengan demikian, semakin luas batasan tim manajemen dalam menganalisa dan memilih berbagai alternatif keputusan dalam proses pengambilan keputusan akan meningkatkan kinerja perusahaan tersebut. Tim yang komprehensif dalam proses pengambilan keputusan memperlihatkan bahwa mereka mempertimbangkan banyak alternatif keputusan dan menganalisa dari berbagai sudut pandang. Selain itu, proses ini melibatkan pengujuan masing-masing alternatif, baik kecocokannya dengan sumberdaya internal, maupun kesesuaian dengan kondisi eksternal. Dengan proses yang demikian, kemungkinan perusahaan untuk memutuskan keputusan terbaik bagi perusahaannya menjadi semakin besar.

Diterimanya hipotesis 6 mengindikasikan bahwa integrasi siosial yang kuat antar anggota-anggota tim manajemen akan meningkatkan kinerja perusahaan melalui kemudahan konsensus dan efisiensi kerja sebagai dampak keterikatan antar anggota, terutama keterikatan emosional yang membentuk kepercayaan dan saling mendukung antara anggota yang satu dengan yang lainnya. Hasil ini mendukung penelitian O'Reilly et al. (1989), Smith et al. (1994), Barrick et al. (2007), Johnson et al. (2007) dan Whiteoak, (2007).

\section{PENUTUP}

Hasil penelitian pada topik ini menunjukkan bahwa diversitas kognitif yang secara konsisten memiliki efek negatif terhadap perusahaan memberikan implikasi agar tim manajemen perusahaan berupaya menyamakan persepsi terhadap isu-isu strategis yang harus dihadapi perusahaan. Masing-masing anggota di dalam tim seharusnya memiliki preferensi tujuan yang sama satu dengan lainnya sehingga proses pengambilan keputusan dibatasi oleh tujuan tujuan tersebut.

Sementara diversitas lainnya, yaitu diversitas latar belakang fungsional dan latar belakang pendidikan, tidak menunjukan hasil yang sesuai dugaan dan tidak konsisten antar pengujian. Kedua variabel tersebut mungkin tidak cukup konsisten sebagai indikator dari keragaman pengetahuan pada konteks penelitian ini sehingga tidak menunjukan hasil yang sama dengan banyak penelitian sebelumnya. BPR merupakan perusahaan perbankan dengan skala kecil yang beroperasi dalam regulasi ketat yang mungkin mengakibatkan efek keragaman pengetahuan tidak terlalu berpengaruh karena direduksi oleh pengaruh serangkaian regulasi yang harus dipatuhi oleh BPR dalam mengambil keputusan.

Selain itu, perusahaan diharapkan untuk melakukan proses pengambilan keputusan yang komprehensif dan membangun integrasi sosial antar anggota tim manajemen mereka yang mana akan memberikan dampak positif terhadap perusahaan. Proses pengambilan keputusan yang komprehensif mampu mengarahkan perusahaan untuk memilih alternatif keputusan terbaik dari berbagai pilihan yang dikemukakan dalam proses tersebut. Integrasi sosial yang kuat di dalam tim menciptakan efisiensi di dalam tim dalam menjalankan tugas manajerialnya, memperlihatkan kekompakan antar anggota yang dapat juga memberikan efek integrasi dari semua anggota/karyawan di dalam perusahaan.

Penelitian ini memliki keterbatasan dalam proses pengumpulan data yang mana menggunakan kuesioner yang diisi sendiri oleh responden. Proses ini dapat menjadi bias karena kecenderungan seseorang yang overvalue dalam menilai diri sindiri. Homogenitas sampel juga dapat mengurangi generalisasi hasil penelitian ini sehingga penelitian selanjutnya perlu mempertimbangkan cakupan industri yang lebih banyak. Selain itu, penelitian selanjutnya dibutuhkan dalam mengelaborasi efek interaksi antara masing-masing variabel diversitas dalam menjelaskan kinerja perusahaan.

\section{DAFTAR PUSTAKA}

Bantel, KA. dan SE. Jackson. 1989. Top Management and Innovation in Banking: Does the Compotition of the Top Team Make a Difference. Strategic Management Journal. 10. 107-124.

Baron, RM. dan DA. Kenny. 1986. The Moderator-Mediator Variable Distinction in 
Social Psychological Research: Conceptual, Strategic, and Statistic Considerations. Journal of Personality and Social Psychology. 51 (6). 1173-1182.

Barsade, SG., AJ. Ward, JD. Turner dan JA. Sonnanfeld. 2000. To Your Heart's Content: A Model of Affective Diversity in Top Management Teams. Administrative Science Quarterly. 45 (4). 802-836.

Bunderson, JS. 2003. Teams Memeber Functional Background and Involvement in Management Teams: Direct Effect and The Moderating Role of Power Centralization. Academy of Management Journal. 46 (4). 458-474.

Bunderson, JS. dan KM. Sutclife. 2002. Camparing Alternative Conceptualization of Functional Diversity in Management Teams: Process and Performance Effect. Academy of Management Journal. 45 (5). 875-893.

Chattopadhyay, P., WH. Glick, CC. Miller dan GP. Huber. 1999. Determinants of Executive Beliefs: Comparing Functional Condition and Sosial Influence. Strategic Management Journal, 20 (8). 763-789.

Chorn, NH. 1991. The "Alignment" Theory: Creating Strategic Fit. Management Decision. 29 (1). 20-24.

Chou, SY. 2011. Group Sosial Integration: The Role of Demographic Diversity and Percieved Dissimilarity. International Journal of Business and Public Administration. 8 (1).

Cunningham, GB. 2007. Perceptions as Reality: The Influence of Actual and Perceived Demographic Dissimilarity. Journal of Business and Psychology. 22 (1). 79-89.

Dahlin, KB., LP. Weingart dan PJ. Hinds. 2005. Team Diversity and Informatiion Use. Academy of Management Journal. 48 (6). 1107-1123.

Finkeilstein, S., DC. Hambrick dan AA. Cannella. 2009. Strategic Leadership: Theory and Research on Executive,
Top Management Team, and Boards. Oxford University Press.

Frederickson, JW. 1984. The Comprehensiveness of Strategic Decision Processes: Extension, Observations, Future Directions. Academy of Management Journal. 27 (3). 445-466.

Frederickson, JW. dan TR. Mitchell. 1984. Strategic Decision Processes: Comprehensiveness and Performance in an Industry with an Unstable Environment. Academy of Management Journal. 27 (2). 399-423.

Goll, I., RB. Sambharya dan LA. Tucci. 2001. Top Management Team Composition, Corporate ideology, and Firm Performace. Management International Review. 41 (2).

Grant, RM. 1996. Toward a Knowledge-Based Theory of The Firm. Strategic Management Journal. 17. 109-122.

Hambrick, DC. dan PA. Mason. 1984. The organization as a reflection of its top managers. Academy of Management Riview. 9 (2). 193-206.

Hambrick, DC., Ts. Cho dan MJ. Chen. 1996. The Influence of Top Management Team on Firm's Competitive Moves. Administrative Science Quarterly. 41 (4). 659-684.

Harrison, DA. dan KJ. Klein. 2007. What the Difference? Diversity Constructs as Separation, Variety, or Disparity in Organization. Academy of Management Riview. 32 (4). 1199-1229.

Hedlund, G. 1994. A Model of Knowledge Management and The N-Form Corporation. Strategic Management Journal. 15. 73-90.

Iaquinto, AL. dan JW. Frederickson,. 1997. Top Management Agreement about the Strategic Decision Process: A Test of Some of Its Determinants and Consequences. Strategic Management Journal. 18 (1). 63-75.

Johnson, MK., K. Reed, K. Lawrence dan M. Onken. 2007. The Link between Communication and Financial Per- 
formance in Simulated Organizational Teams. Journal of Managerial Issue. 19 (4). 536-553

Kearney, E., D. Gebert dan SC. Voelpel. 2009. When and How Diversity Benefit Teams: The Importance of Team Members' Need For Cognition. Academy of Management Journal. 52 (3). 581-598.

Kerlinger, FN. dan HB. Lee. 2000. Foundations of Behavioral Research. $2^{\text {nd }}$ ed. Harcourt College Publisher.

Kiesler, S. dan L. Sproul. 1982. Managerial Responses to Changing Environments: Perspectives on Problem Sensing from Sosial Cognition. Administrative Science Quarterly. 27. 558.

Knight, D., CL. Pearce, KG. Smith, JD. Olian, HP. Sims dan KA. Smith. 1999. Top Management Team Diversity, Group Process, and Strategic Consensus. Strategic Management Journal. 20 (5). 445-465.

Lankau, MJ., A. Ward, A. Amason, T. Ng, JA. Sonnenfield dan BR. Agle. 2007. Examining the Impact of Organizational Value Dissimilarity in Top Management Teams. Journal of Managerial Issues. 19 (1). 11-34.

Miller, C. 2008. Decisional Comprehensiveness and Firm Performance: Toward a More Complete Understanding. Journal of Behavioral Decision Making. 21. 598620.

Miller, C., LM. Burke dan WH. Glick. 1998. Cognitive Diversity among UpperEchelon Executive: Implication for Strategic Decision Processes. Strategic Management Journal. 19 (1). 39-58.

Mintzberg, H., JB. Lampel, JB Quinn dan S. Ghoshal. 2003. The Strategy Process. Concepts, Contexts, Cases. Vol. 3. Prentice Hall.

Neilsen, S. 2010. Top Management Team Diversity: A riview of Theories and Methodologies. International Journal of Management Riviews.
Norburn, D., dan S. Birley. 1988. Top Management Team and Corporate Performance. Strategic Management Journal. 9 (3). 225-237.

O'Reilly, CA., DF. Caldwell dan WP. Barnet. 1989. Work Group Demography, Sosial Integration, and Turnover. Administrative Science Quarterly. 34. 21-37.

Oslon, BJ., S. Parayitam dan NW. Twigg. 2006. Mediating Role og Strategic Choice Betwen Top Management Team Diversity and Firm Performance: Upper Echelons Theory Revisited. Journal of Business and Management. 12 (2).

Papadakis, VM., S. Lioukas dan D. Chambers. 1998. Strategic Decision-Making Processes: The Role of Management and Context. Strategic Management Journal. 19 (2).

Reagans, R. 2005. Preferences, Identity, and Competition: Predicting Tie Strength from Demographic Data. Academy of Management Journal. 51 (9). 13741383.

Simons, T., LH. Pelled dan KA. Smith. 1999. Making Use of Difference: Diversity, Debate, and Decision Comprehensiveness in Top Management Team. Academy of Management journal, 42 (6), 662-673.

Simsek, Z., JF. Veiga., MH. Lubatkin., and RN. Dino. 2005. Modeling the Multilevel Determinants of Top Management Team Behavioral Integration. Strategic Management Journal. 48 (1). 69-84.

Smith, KG., KA. Smith, JD. Olian, P. Henry, J. Sims, DP. O'Bannon dan JA. Scully. 1994. Top Management Team Demography and Process: The Role of Sosial Integration and Communication. Administrative Sciene Quarterly. 39 (3). 412-438.

Sparrowe, RT., RC. Liden, SJ. Wayne dan ML. Kraimer. 2001. Sosial Networks and the Performance of Individuals and Groups. Academy of Management Journal. 44 (2). 316-325. 
Srivastava, A. dan H. Lee. 2008. Firm Performance and Top Management Team Age, Tenure, and Education: A Research Synthesis. International Journal of Business Research. 8 (2).

Venkatraman, N. 1989. The Concept of Fit in Strategy Research: Toward Verbal and
Statistical Correspondence. Academy of Management Journal. 14 (3). 423-444.

Weirsema, MF. dan KA. Bantel. 1992. Top Management Team Demography and Corporate Strategic Change. Academy of Management Journal. 35 (1). 91121. 